\title{
EFEKTIVITAS PENGGUNAAN METODE ANALISIS STATISTIK OLEH SATLANTAS POLRES PADANG PARIAMAN SEBAGAI UPAYA MENURUNKAN ANGKA KECELAKAAN LALULINTAS
}

\author{
Fevi Indra \\ Program Magister Ilmu Hukum,Universitas Ekasakti, Padang, Indonesia \\ Email: feviindra5@gmail.com
}

\begin{abstract}
The use of the Traffic Accident statistical analysis method by the Padang Pariaman Police Traffic Unit as an Effort to Reduce Traffic Accident Rates is by means of quantitative analysis, namely by including definite and qualitative figures, namely by not including exact figures, but only mentioning "Increase", "Decrease". "levels of "worrying", and so on. In order to determine the relationship and interrelationships between accident variables, the statistical analysis method used is correlation. There are two criteria highlighted for correlation analysis, namely whether the existing sample data provide sufficient evidence that there is a relationship between variables. And second, if there is a relationship, how strong is the relationship between these variables. The variables tested were the type of accident, the cause of the accident, the behavior of the driver that caused the accident, the type of vehicle, the time of the accident, and the profession of the perpetrator of the accident. Effectiveness The use of statistical analysis methods by the Padang Pariaman Police Traffic Unit as an Effort to Reduce Traffic Accident Rates is already effective. It can be seen that there is a decrease in the number of accidents, although in 2019 there was an increase but in 2020 there was a decrease in the number of accidents, namely 284 cases from 363 cases in 2019. This statistical analysis data is very useful for the community as an early warning to be more careful when passing through roads where accidents often occur.
\end{abstract}

Keywords: Effectiveness, Statistical analysis method, Accident, Traffic

\begin{abstract}
ABSTRAK
Penggunaan metode analisis statistik Kecelakaan Lalulintas Oleh Satlantas Polres Padang Pariaman Sebagai Upaya Menurunkan Angka Kecelakaan Lalulintas adalah dengan cara analisis secara kuantitatif yaitu dengan mencantumkan angka angka secara pasti dan kualitatif yaitu dengan tidak mencantumkan angka angka secara pasti, melainkan hanya menyebut "Peningkatan", "Penurunan" tingkat yang "mencemaskan", dan sebagainya. Guna mengetahui hubungan dan keterkaitan antar variabel kecelakaan, metode analisis statistik yang digunakan adalah Korelasi. Terdapat dua kriteria yang disoroti untuk analisis korelasi, yaitu apakah data sampel yang ada menyediakan cukup bukti bahwa ada kaitan antar variabel. Dan yang kedua, jika ada hubungan, seberapa kuat hubungan antar variabel tersebut. Variabel yang diujikan yaitu jenis kecelakaan, penyebab kecelakaan, perilaku pengemudi penyebab kecelakaan, jenis kendaraan, waktu terjadinya kecelakaan, dan profesi pelaku kecelakaan. Efektivitas Penggunaan metode analisis statistik oleh Satlantas Polres Padang Pariaman Sebagai Upaya
\end{abstract}


Menurunkan Angka Kecelakaan Lalulintas adalah sudah efektif. Hal ini terlihat terdapat penurunan angka kecelakaan walaupun pada tahun 2019 terdapat kenaikan namun tahun 2020 terdapat penurunan angka kecelakaan yaitu sebanyak 284 kasus dari 363 kasus pada tahun 2019. Data Analisis statistik ini menjadi sangat bermanfaat bagi masyarakat sebagai peringatan dini agar lebih berhati-hati ketika melewati ruas jalan dimana sering terjadi kejadian kecelakaan.

Kata Kunci: Efektivitas, Metode analisis statistik, Kecelakaan, Lalu lintas

\section{PENDAHULUAN}

Pesatnya perkembangan pemilikan alat transportasi bermotor dalam tahun-tahun terakhir, digabungkan pula dengan masyarakat dengan umur yang relatif belia serta beragamnya tipe alat transportasi sudah menyebabkan permasalahan musibah yang bertambah memburuk. Banyak dari para korban ini memperoleh luka-luka yang hendak menyebabkan cacat sama tua hidup serta dengan cara keuangan hendak memberati keluarga mereka serta warga. Tingkatan kematian dampak musibah kemudian rute di negara-negara lagi bertumbuh telah menggapai 20 hingga 70 kali serupa besar dengan tingkatan identik di negara-negara pabrik. Lagi pula indikator fatalitas (Prosentase yang tewas kepada keseluruhan korban) tinggi. ${ }^{1}$

Untuk memaksimalkan, pendekatan campur tangan keamanan jalur butuh didapat dalam 3 jenjang yang berlainan ialah membangkitkan perhatian, konsep kelakuan keamanan jalur prioritas serta program 5 tahun buat keamanan jalur. Keamanan jalur ialah permasalahan sosial yang multidimensional yang mengaitkan banyak lembaga penguasa alhasil negeri wajib menggenggam kedudukan penting dalam memelopori, mengorganisasi, serta mengkoordinasi dengan cara nasional dalam melawan permasalahan keamanan jalur dinegaranya. Didalam membongkar permasalahan keamanan serta musibah jalur, manajemen kemudian rute jadi aspek berarti. Buat itu amatlah berarti buat meningkatkan sistem data keamanan serta musibah jalur selaku aplikasi dari manajemen kemudian rute itu sendiri. Salah satu tujuan manajemen kemudian rute yang diimplementasikan dalam pengembangan sistem data keamanan serta musibah jalur merupakan gimana tingkatkan tingkatan keamanan, keamanan, kedisiplinan serta kelancaran konsumen yang bisa diperoleh seluruh pihak.

Buat memencet nilai musibah kemudian rute yang dialami amat besar, usaha ke depan ditunjukan pada penyelesaian dengan cara menyeluruh yang melingkupi usaha pembinaan, penangkalan, pengaturan, serta penguatan hukum. Usaha pembinaan itu dicoba lewat kenaikan keseriusan pembelajaran lalu rute serta konseling hukum dan pembinaan pangkal energi orang. Sebaliknya usaha penangulangan musibah lalulintas membutuhkan bermacam strategi dalam penerapannya.

Buat memencet nilai musibah kemudian rute yang dialami amat besar, usaha ke depan ditunjukan pada penyelesaian dengan cara menyeluruh yang melingkupi usaha pembinaan, penangkalan, pengaturan, serta penguatan hukum. Usaha pembinaan itu dicoba lewat kenaikan keseriusan pembelajaran lalu rute serta konseling hukum dan pembinaan pangkal energi orang.

\footnotetext{
${ }^{1}$ Metta Kartika, Analisis Faktor Penyebab Kecelakaan Lalu Lintas pada Pengendara Sepada Motor di Wilayah Depok, Skripsi, Universitas Indonesia, Jakarta, 2009.
} 
Kemudian Rute serta Angkutan Jalur dalam perihal ini ialah aspek aktivitas yang memiliki andil amat berarti sebab mempunyai posisi penting dalam memperlancar cakra perekonomian, memperkukuh aliansi serta kesatuan dan bisa pengaruhi seluruh pandangan kehidupan bangsa serta negeri yang berwawasan area buat menggapai tujuan pembangunan nasional. Salah satu usaha penyelesaian musibah lalulintas merupakan dengan pembuatan statistik musibah yang terjalin. Statistik muat informasi mengenai kondisi musibah yang terjalin semacam jumlah, pelakon serta korban, pemicu, durasi terjalin serta posisi peristiwa.

Bersumber pada perihal itu kasus yang diulas merupakan pemakaian tata cara analisa statistik musibah lalulintas oleh Satlantas Polres Padang Pariaman selaku usaha merendahkan nilai musibah lalulintas.

\section{METODE PENELITIAN}

Spesifikasi penelitian adalah deskriptif analitis, dengan metode pendekatan yuridis normative didukung oleh yuridis empiris. Jenis data yang digunakan adalah data sekunder dan data primer. Data sekunder diperoleh dari studi dokumen, data primer diperoleh dengan cara wawancara. Data yang diperoleh kemudian dianalisa secara kualitatif.

\section{PEMBAHASAN}

\section{A. Penggunaan Metode Analisis Statistik Kecelakaan Lalulintas Oleh Satlantas Polres Padang Pariaman Sebagai Upaya Menurunkan Angka Kecelakaan Lalulintas}

Statistik analisa musibah kemudian rute dalam penggunaannya bisa dibedakan antara kuantitatif serta kualitatif. Kuantitatif ialah dengan memuat nilai nilai dengan cara tentu serta kualitatif ialah dengan tidak memuat nilai nilai dengan cara tentu, melainkan cuma mengatakan "Kenaikan”, “ Penyusutan”.

Statistik pidana bisa menolong petugas penegak hukum dalam mendapatkan cerminan kesalahan yang terdapat di warga ialah mengenai jumlah dan corak kesalahan, kemajuan naik turunya nilai kesalahan, alhasil bisa digunakan buat penangkalan, koreksi, penerapan serta majelis hukum dan tugas- tugas rezim lainya, spesialnya dalam aspek penangulangan kesalahan alhasil pengumpulan materi-materi ini diusulkan dengan selengkap-lengkapnya. ${ }^{2}$

Usaha prevetif merupakan sesuatu wujud usaha yang dicoba oleh kepolisian dimana kepolisian melaksanakan penyelesaian kejahtan dengan melaksanakan patrolipatroli yang dicoba dengan cara terencana serta tertib, tercantum pula upaya penangkalan kesalahan ataupun penerapan kewajiban dengan metode melindungi menjaga kedisiplinan serta menjamin keamanan biasa. ${ }^{3}$

Statistik musibah kemudian rute dipakai selaku informasi yang melukiskan mengenai kondisi musibah kemudian rute dengan cara mutlak. Dengan begitu nilai nilai itu seakan sanggup sendiri dalam berikan maksud untuk dirinya. Misalnya pada jumlah terbentuknya musibah lalulintas. Di area hukum Satlantas Polres Padang Pariaman semenjak tahun 2018 ada nilai jumlah musibah sebesar 280 permasalahan serta pada tahun

2 J. Supranto M.A, Pengantar Statsitik Bidang Hukum, Rineka Cipta, Jakarta, 1995, hlm 78

3 A. Qirom Syamsudin M, Surmaryo E, Kejahatan Anak Suatu Tinjauan Dari Segi Pisikologidan Hukum,Liberti , Yogyakarta, 1985,hlm.46. 
2019 terjalin kenaikan sebesar 363 permasalahan. Sebaliknya pada tahun 2020 terjalin penyusutan ialah sebesar 240 permasalahan musibah lalulintas.

Pengunaan tata cara statistik pidana dalam amatan penyelesaian nilai kejahatan yang besar amat diperlukan dalam mengutip sesuatu kebijaksanaan hukum kejahatan buat meminimalisir serta menanggulangi kesalahan di warga. ${ }^{4}$ Statistik musibah kemudian rute digunakan selaku informasi buat membagikan cerminan hal kemajuan musibah kemudian rute yang terjalin di warga semacam lajunya, tipe- tipe musibah kemudian rute yang muncul, penyelesaiannya. Dalam menganalisa informasi musibah kemudian rute yang berhubungan, statistik diperoleh ilustrasi yang legal serta bisa memantulkan musibah yang terjalin, bagus hal tipe-tipe kecelakaannya ataupun penyebarannya. Tipe musibah yang muncul di area hukum Satlantas Polres Padang Pariaman dibedakan dengan bersumber pada tipe alat transportasi serta tipe tumbukan yang terjalin.

Analisa statistik sendiri dicoba dengan sebagian pendekatan, antara lain analisa nilai musibah bersumber pada pendekatan jarak, Misalnya dengan memakai metode statistik pengawasan mutu buat memilah ruas jalur ataupun posisi rawan musibah (blackspot) dengan jauh serta daya muat yang berlainan. Awal kali merupakan memastikan harga datar datar nilai musibah buat selama jalur, setelah itu dihitung ambang atas serta ambang bawahnya. Ruas yang mempunyai tingkatan musibah diatas ambang atas diucap "out of control". 5

Analisa nilai musibah pula bisa dicoba bersumber pada pendekatan jauh ekspedisi alat transportasi keseluruhan, Dimana dari tata cara kalkulasi ini hendak diperoleh nilai musibah semua bagian, batasan atas serta batasan dasar nilai musibah, serta nilai musibah masing-masing bagian yang ditinjau. ${ }^{6}$ Ada sebagian langkah- langkah dalam pengetesan statistik. Awal, Memastikan anggapan yang hendak dicoba. Anggapan ialah membuat sesuatu statment dengan asumsi-asumsi buat mencoba terdapatnya pertemuan ataupun perbandingan dari kemampuan ruas jalur. Pengetesan anggapan berkaitan dengan pendapatan ataupun antipati sesuatu anggapan. Prinsip pengetesan hipotesa merupakan analogi angka statistik percobaan dengan angka titik kritis dengan anggapan nihil serta alternatifnya. Setelah itu kedua merupakan Jumlah angka percobaan statistik.

Dalam penggunaanya statistik musibah kemudian rute dibedakan antara kuantitatif serta kualitatif, kuantitatif ialah dengan memuat angka-angka dengan cara tentu serta kualitatif ialah dengan tidak memuat angka-angka dengan cara tentu, melainkan cuma mengatakan "kenaikan" "penyusutan" berikutnya dalam ikatan pemakaian statistik pidana oleh kepolisian, hingga dengan cara resmi statistik dipakai bagus selaku bawah kategorisasi pemograman ataupun selaku penilaian kegaitan operasionalnya, sebaliknya dengan cara informal statistik pula digunakan selaku penguat serta pembenar kepada aktivitas operasionalnya. Di sisi itu pemakaian statistik oleh pihak kepolisian dicoba dengan cara akurat ialah dengan mengatakan angka-angka dengan cara akurat, serta dicoba dengan cara sugestif ialah tanpa menyebuatkan angka-angka kesalahan, namun

\footnotetext{
${ }^{4}$ Abdussalam H.R, Kriminologi, Restu Agung, Jakarta, 2007, hlm 56

${ }^{5}$ Wawancara dengan Kanit Lantas Polres Padang Pariaman pada tanggal 12 Oktober 2021

${ }^{6}$ Wawancara dengan petugas pada Satlantas Polres Padang Pariaman pada tanggal 13 Oktober 2021
} 
cuma mengatakan misalnya terdapatnya “ekskalasi”, "penyusutan” serta sebagainya.

\section{B. Efektivitas Penggunaan Metode Analisis Statistik Oleh Satlantas Polres Padang Pariaman Sebagai Upaya Menurunkan Angka Kecelakaan Lalulintas}

Dasar kemudian rute Polres Padang Pariaman melaksanakan usaha merendahkan nilai ataupun tingkatan musibah kemudian rute dengan sungguh-sungguh. Salah satunya ialah dengan memakai tata cara analisa statistik. Statistik musibah kemudian rute diperlukan untuk menampilkan serta mengukur kondisi dalam lalu rute, dan statistik musibah kemudian rute bisa dipakai selaku sesuatu usaha buat mencoba keberhasilan perundang- undangan serta aksi penghukuman yang jatuhkan.

Analisa statistik bisa jadi referensi dalam mengutip aksi selaku usaha kurangi nilai musibah kemudian rute. Perihal ini sebab dalam melaksanakan analisa statistik itu kita bisa mengenali informasi detil peristiwa musibah, ada pula halaman input buat membuktikan situasi marka serta pancang di tiap ruas jalur tempat terbentuknya musibah. Informasi Analisa statistik ini jadi amat berguna untuk mayarakat selaku peringatan dini supaya lebih berjaga-jaga kala melampaui ruas jalur dimana kerap terjalin peristiwa musibah, tidak hanya itu data ini berarti untuk biro kepolisian serta pula biro lain semacam biro perhubungan buat membenarkan bila terdapat bagian marka serta pancang yang cacat.

Pemakaian informasi analisa statistic buat kurangi musibah lalulintas di area hokum Satlantas Polres Padang Pariaman telah efisien dalam kurangi nilai musibah lalulintas. Perihal ini nampak ada penyusutan nilai musibah meski pada tahun 2019 ada ekskalasi tetapi tahun 2020 ada penyusutan nilai musibah ialah sebesar 284 permasalahan dari 363 permasalahan pada tahun 2019.

Penyelesaian beralasan statistik pidana dicoba pula dengan mencermati wilayah rawan musibah (blackspot) merupakan wilayah yang memiliki nilai musibah besar, efek serta kemampuan musibah yang besar pada sesuatu ruas jalur. Posisi rawan musibah dipecah jadi 3 (3) bagian ialah:

1. Blackspot ataupun posisi rawan musibah berplatform posisi tunggal.

2. Blacklink ataupun posisi rawan musibah berplatform ruas jalur.

3. Blackarea ataupun posisi rawan musibah berplatform area.

Determinasi blackspot dicoba dengan melaksanakan 2 (2) jenjang, selaku selanjutnya:

1. Membagikan angka ataupun berat buat tiap peristiwa musibah;

2. Melaksanakan pemeringkatan bersumber pada jumlah angka ataupun berat dalam sesuatu posisi.

Pembobotan dicoba dengan memikirkan situasi terparah musibah kemudian rute. Salah satu usaha melindungi dicoba dengan membuat peraturan-peraturan buat menghindari ataupun minimun kurangi terbentuknya musibah kemudian rute ataupun seandainya kecelakaanpun sedang wajib terjalin minimun menghindari ataupun kurangi dampak yang parah pada korban ialah berbentuk luka berat apalagi korban tewas.

Usaha itu misalnya dengan terdapatnya peranan mengenakan helm standar nasional Indonesia (SNI) buat juru mudi alat transportasi bermotor cakra 2, keharusan menggunakan sabuk keamanan buat juru mudi alat transportasi bermotor cakra 4 apalagi 
dalam Hukum Kemudian Rute no 22 tahun 2009 terdapatnya keharusan menghidupkan lampu penting pada siang hari buat alat transportasi bermotor cakra 2, seluruh itu dicoba selaku usaha buat kurangi tingkatan kecelakan kemudian rute.

Dalam berikan jasa serta proteksi hukum pada warga spesialnya di aspek kemudian rute, barisan petugas Polres Padang Pariaman spesialnya polisi Kemudian Rute senantiasa melangsungkan aktivitas yang berjudul patuh lalu rute di jalur raya. Aktivitas itu berisikan keadaan yang berkaitan dengan permasalahan kemudian rute, semacam menampilkan bermacam gambar yang melukiskan terbentuknya musibah di jalur dan lukisan rambu- rambu kemudian rute serta menampilkan aturan metode pemakaian helm yang betul untuk keamanan berkendara di jalur raya. Aktivitas itu bermaksud supaya warga lebih memahami serta menguasai hal permasalahan kemudian rute dan bermaksud supaya meningkatkan pemahaman warga hendak berartinya patuh lalu rute di jalur.

Dalam bagan memencet terbentuknya musibah di jalur ataupun perbuatan pidana yang lain, dasar kemudian rute Polres Padang Pariaman mengaktifkan pergerakkan mobil langlang cahaya biru (Blue Light Patrol). Dasar kemudian rute Polres Padang Pariaman melaksanakan langlang biru di selama rute rawan langgar di jalur spesialnya durasi petang hingga menjelang tengah malam ketika suasana arus kemudian rute marak di jalanan. Tidak hanya itu, aktivitas ini dicoba buat menghindari terbentuknya kelakuan pacuan buas pada dikala malam pekan sebab malam pekan ialah rawan terbentuknya kelakuan pacuan buas.

Salah satu Usaha penindakan yang dicoba Polres Padang Pariaman merupakan dengan melaksanakan Sosialisai keamanan, keamanan, kedisiplinan lalu rute pada konsumen Jalur dan membagikan bimbingan mengenai berartinya menaati ketentuan lalu rute di jalur raya supaya bebas dari musibah pada dikala berkendara. Program aktivitas pemasyarakatan keamanan, keamanan serta kedisiplinan kemudian rute diimplementasikan lewat aktivitas pencerahan dengan cara langsung, konseling, pembuatan plakat, leaflet, etiket, novel petunjuk, novel, lomba-lomba ataupun keelokan.

Salah satu usaha penindakan yang dicoba Polres Padang Pariaman ialah dengan melaksanakan pemasangan slogan dititik rawan musibah supaya juru mudi bisa memandang serta mengenali dan lebih berhati batin dalam mengemudikan alat transportasi. Kenaikan pemahaman pada para juru mudi mengenai kehati- hatian dalam berkendara pemberitahuan semacam ini pula berikan akibat positif yang lain semacam kurangi efek kecelekaan yang dapat menimbulkan orang lain terserang akibat kerukian modul serta raga orang lain.

Dasar kemudian rute Polres Padang Pariaman pula membuat pembatas jalur ataupun median dengan bukaan di tiap simpang. Pembuatan pembatas jalur ataupun median ini bermaksud buat mengestimasi terbentuknya musibah bentur depan- depan semacam yang kerap terjalin pada ruas Jalur Raya Padang Pariaman, ialah supaya juru mudi tidak memakai rute kebalikannya buat mendahulukan, alhasil kemampuan terbentuknya musibah bisa diminimalisir. Bukaan pada tiap simpang dilengkapi dengan deret menunggu. Pembuatan putaran balik (U-Turn) di ruas jalur Padang Pariaman dengan estimasi daya muat kemudian rute yang amat padat dan, kelancaraan kemudian rute sebab kurangi bentrokan di Simpang dan kurangi musibah sebab alat transportasi jadi satu arah alhasil kurangi musibah langsung serta memudahkan juru mudi yang hendak 
melaksanakan putar arah.

Disamping itu mereka pula melaksanakan pembinaan di sekolah-sekolah. Alat transportasi bermotor telah ialah bagian yang tidak terpisahkan dari kehidupan orang. Zaman moderen semacam saat ini alat transportasi bermotor ialah perlengkapan pemindahan penting di area Indonesia. Situasi ini ditopang oleh keringanan membeli alat transportasi bermotor spesialnya sepeda motor, cuma dengan jumlah duit ratusan ribu rupiah telah dapat mempunyai alat transportasi bermotor dengan metode angsuran. Kondisi ini berakibat positif serta minus untuk kehidupan orang.

Positifnya orang hendak lebih gampang dalam melakukan seluruh aktifitasnya, sedangkan negatifnya jumlah alat transportasi terus menjadi banyak yang menimbulkan kemacetan terjalin dimana-mana, Disamping itu banyak sekali kanak-kanak yang belum waktunya mendapatkan ijin mengemudi (SIM) apalagi tidak memiliki SIM sudah memandu alat transportasi bermotor khsusnya alat transportasi bermotor bagus cakra 2 ataupun cakra. ${ }^{4}$

Realitas semacam ini susah buat dijauhi, sebab kehidupan modern butuh efisien serta berdaya guna. Oleh sebab itu pihak polri melangsungkan kerjasama dengan pihak sekolah-sekolah sambungan bagus sekolah sambungan awal ataupun sekolah sambungan tingkatan atas buat membagikan konseling pada para anak didik mengenai keadaan yang terpaut dengan kemudian rute jalur raya. Data terpaut dengan kemudian rute ini hendak amat menolong mereka spesialnya mereka yang dapat mengemudikan alat transportasi bermotor buat dapat berkendaraan dengan bagus.

Dasar kemudian rute Polres Padang Pariaman pula mengadakan safety riding selaku usaha memencet nilai musibah kemudian rute. Memperjuangkan buat kurangi tingkatan musibah kemudian rute ialah usaha yang wajib lalu menembus dicoba oleh bermacam pihak spesialnya aparat yang terpaut langsung dengan permasalahan itu semacam aparat kepolisian. Salah satu usaha yang dicoba oleh Polres Padang Pariaman merupakan mengadakan Safety Riding. Safety Riding serupa perihalnya dengan sebutan Safety Driving buat konsumen alat transportasi cakra 4 ataupun lebih, sebutan Safety Riding merujuk pada sikap berkendara yang dengan cara sempurna wajib mempunyai tingkatan keamanan yang lumayan untuk diri sendiri ataupun orang lain.

\section{KESIMPULAN}

Guna mengetahui hubungan dan keterkaitan antar variabel kecelakaan, metode analisis statistik yang digunakan adalah Korelasi. Efektifitas Penggunaan Metode Analisis Statistik Oleh Satlantas Polres Padang Pariaman Sebagai Upaya Menurunkan Angka Kecelakaan Lalulintas adalah sebagai acuan dalam mengambil tindakan sebagai upaya mengurangi angka kecelakaan lalu lintas. Melalui analisis statistik tersebut dapat diketahui data detil kejadian kecelakaan, terdapat pula laman input untuk menunjukan kondisi marka dan rambu di setiap ruas jalan tempat terjadinya kecelakaan. 


\section{DAFTAR PUSTAKA}

Metta Kartika, Analisis Faktor Penyebab Kecelakaan Lalu Lintas pada Pengendara Sepada Motor di Wilayah Depok, Skripsi, Universitas Indonesia, Jakarta, 2009.

J. Supranto M.A, Pengantar Statsitik Bidang Hukum, Rineka Cipta, Jakarta, 1995, hlm 78.

A. Qirom Syamsudin M, Surmaryo E, Kejahatan Anak Suatu Tinjauan Dari Segi Pisikologidan Hukum,Liberti, Yogyakarta, 1985,hlm.46.

Abdussalam H.R, Kriminologi, Restu Agung, Jakarta, 2007, hlm 56. 